\title{
PERLINDUNGAN HUKUM TERHADAP JASA PENYELENGGARA KEGIATAN UNTUK KEBERLANJUTAN USAHA PERUSAHAAN JASA PENYELENGGARA KEGIATAN
}

\author{
Otih Handayani
}

\begin{abstract}
Abstrak
Penelitian ini membahas perlindungan hukum terhadap bisnis penyelenggara kegiatan dalam kehidupan modern. Rumusan masalah yang diambil adalah (1) Bagaimana implementasi hak dan kewajiban perusahaan jasa penyelenggara kegiatan dan pengguna jasa dalam perspektif hukum perikatan, apa saja kendala yang timbul serta bagaimana cara mengatasi permasalahan tersebut ? (2) Bagaimana perlindungan hukum bagi perusahaan jasa penyelenggara kegiatan dan pengguna jasa dalam kaitannya dengan keberlanjutan bisnis jasa penyelenggara kegiatan antara perusahaan jasa penyelenggara kegiatan dengan pengguna jasa ? Kesimpulan penelitian adalah perusahaan jasa penyelenggara acara dalam sistem bisnis modern dan bernuansa legalitas lebih membutuhkan perlindungan hukum, hal ini disebabkan perusahaan jasa penyelenggara kegiatan melaksanakan kewajibannya lebih dahulu sedangkan pengguna jasa lebih awal menerima haknya. Peneliti menemukan kendala-kendala dalam pemenuhan hak dan kewajiban disebabkan adanya ketidaktahuan, ketidakmampuan ataupun ketidakmauan para pihak termasuk pihak luar dalam melaksanakan pasal 1338 KUHPerdata dan azas-azas perjanjian.

Kata kunci: Perlindungan Hukum, Jasa Penyelenggara Kegiatan
\end{abstract}

\begin{abstract}
This study discusses on Legal Protection of Event Organizer For Business Sustainability Of Event Organizer Company. The questions posed are (1) How is the implementation of rights and obligations of event organizer companies and service users in the perspective of agreement law, what are the obstacles that arise as well as how to overcome these problems? (2) What is the legal protection for event organizers and service users in the event organizer service business in relation to the continuity of the service provider business activities between event organizers and service users? The author found that Event Organizer in modern business systems and legality is more in need of legal protection, this is because the Event Organizer carries out its obligations first while service users receive their rights earlier. The author finds obstacles in the fulfillment of rights and obligations due to ignorance, incapacity or unwillingness of the parties including outsiders in implementing article 1338 of the Civil Code and the principles of the agreement.
\end{abstract}

Keywords: Legal Protection, Event Organizer Services

\section{Pendahuluan}

Riset dari Nielsen Advertising Information Services mencatat belanja iklan di Indonesia pada tahun 2015 mengalami pertumbuhan sebesar 7\% (tujuh persen), total untuk 
TV dan media cetak, dengan nilai mencapai Rp.118.000.000.000.000,00 (seratus delapan belas triliun rupiah).

Kemajuan pesat di dunia bisnis memerlukan alternatif periklanan ketika penggunaan media cetak maupun elektronik tidak lagi efektif. Kesuksesan suatu kegiatan yang berskala besar seperti product launching, press conference, atau acara-acara promosi kadangkala di tentukan oleh panitia/penyelenggara yang melakukan kegiatan tersebut. Jasa penyelenggara kegiatan secara praktis merupakan bentuk konkrit dari bisnis public relations. Pengguna jasa menggandeng perusahaan jasa penyelenggara kegiatan demi efisiensi dan keberhasilan kegiatan tersebut.

Secara umum, bisnis ini masih jarang peminatnya dan dapat diartikan pula jarang pesaing sehingga merupakan peluang bisnis yang harus ditangkap. Peluang ini ditangkap oleh raksasa-raksasa Internasional seperti J. Walter Thompson, Dentsu, BBDO, Ted Bates, O\&M, Saatchi \& Saatchi di Indonesia sedikit banyak telah memperkenalkan praktik-praktik kreatif yang sedikit lebih maju.

Surat Edaran Direktur Jenderal Pajak Nomor SE-11/PJ.53/2003 tentang Perlakuan Pajak Pertambahan Nilai Atas Jasa Penyelenggara Kegiatan merupakan peraturan yang mewajibkan perusahaan jasa penyelenggara kegiatan membayar pajak atas kegiatannya, hal ini secara langsung memberikan hak kepada perusahaan jasa penyelenggara kegiatan untuk mendapat perlindungan hukum atas kegiatannya.

Bisnis jasa penyelenggara kegiatan merupakan bisnis yang sangat menguntungkan dengan margin laba berkisar 20-30\% dari modal untuk sebuah acara. Banyaknya kegiatan yang dibuat dalam waktu sangat singkat, hubungan pertemanan yang kental tanpa disertai perikatan sebagai dasar penyelenggaraan kegiatan dan ketidaktahuan akan konsekuensi perjanjian terhadap hak dan kewajiban masing-masing pihak adalah sebagian masalah yang sering terjadi pada bisnis jasa penyelenggara kegiatan. Perlindungan hukum terhadap perusahaan jasa penyelenggara kegiatan dan pengguna jasa dalam perikatan jasa penyelenggara kegiatan adalah suatu keharusan agar hak dan kewajiban para pihak dapat diatur secara lengkap, konkret dan dilaksanakan sesuai dengan yang diperjanjikan. 


\section{Tujuan Penelitian}

Penelitian ini memiliki dua tujuan pokok, yaitu tujuan objektif dan tujuan subjektif, dengan penjelasannya adalah sebagai berikut :

\section{Tujuan Objektif}

a. Untuk mengetahui sudut pandang dan implementasi pemenuhan hak dan kewajiban menurut perusahaan jasa penyelenggara kegiatan dan pengguna jasa serta penyebab terjadinya kendala-kendala pada bisnis jasa penyelenggara kegiatan.

b. Menyusun cara pemenuhan hak dan kewajiban pada bisnis jasa penyelenggara kegiatan sesuai dengan hukum perikatan yang berlaku di Indonesia maupun di luar Indonesia sehingga hak dan kewajiban para pihak dapat diatur secara lengkap, konkret dan dilaksanakan sesuai dengan yang diperjanjikan.

\section{Tujuan Subjektif}

a. Penelitian ini ditujukan untuk menambah pengetahuan peneliti tentang perlindungan hukum terhadap perusahaan jasa penyelenggara kegiatan dan pengguna jasa dalam perikatan penggunaan jasa.

b. Penelitian ini dilakukan untuk memperluas wacana pemikiran dan pengetahuan peneliti dalam hukum perdata, khususnya mengenai Hukum Perikatan.

\section{Manfaat Penelitian}

Ada beberapa manfaat dari penelitian ini yaitu manfaat teoritis dan manfaat praktis, dengan uraian sebagai berikut :

\section{Manfaat Teoritis}

Secara teoritis, hasil dari penelitian ini diharapkan dapat menjadi referensi atau masukan bagi perkembangan hukum perikatan khususnya hukum bisnis pada jasa penyelenggara kegiatan sehingga hak dan kewajiban para pihak dapat dilindungi, berkelanjutan dan meningkatkan kerjasama para pihak serta menjadikan bisnis jasa penyelenggara kegiatan sebagai bisnis yang menjanjikan.

\section{Manfaat Praktis}

a. Manfaat untuk peneliti

Dapat mengetahui teori dan implementasi hukum perikatan dalam bisnis jasa penyelenggara kegiatan, sehingga dapat memotivasi untuk menjadi pengguna jasa, 
perusahaan jasa penyelenggara kegiatan maupun konsultan di bidang hukum bisnis khususnya jasa penyelenggara kegiatan.

b. Manfaat untuk praktisi

Dapat menjadi salah satu sumber informasi untuk mengimplementasikan dalam bisnis jasa penyelenggara kegiatan sehingga dapat menjalankan bisnis dengan sehat yaitu menguntungkan dan berkelanjutan.

c. Manfaat untuk pembaca

Dapat meningkatkan pengetahuan tentang bisnis jasa penyelenggara kegiatan dalam kerangka hukum perikatan.

d. Manfaat untuk penelitian selanjutnya

Dapat memberikan referensi yang baik dalam penelitian hukum perikatan khususnya hukum bisnis pada jasa penyelenggara kegiatan.

\section{Metode}

Penelitian ini menggunakan pendekatan yang bersifat deskriptif analitis serta kajian literature dari berbagai sumber informasi dan data yang peneliti peroleh sebagai acuan. Metode penelitian yang digunakan adalah deskriptif kualitatif menitikberatkan pada observasi dan suasana ilmiah (natural setting). Peneliti terjun langsung untuk melakukan wawancara dan pengamatan untuk mendiskripsikan latar belakang dan memahami keadaan yang terbatas jumlahnya dengan fokus yang mendalam serta rinci agar dapat menemukan dan mengidentifikasi masalah sehingga dapat menghasilkan kesimpulan secara umum.

Sumber Data Primer dalam penelitian ini terdiri dari beberapa pihak yaitu Sdr. Rio Abdurrahman pemilik CV Kardus Communication Cirebon dan Sdr. Arya selaku Account Executive PT Indonesia Klikkanan Raya. Lokasi Penelitian dilakukan pada beberapa perusahaan jasa penyelenggara kegiatan, diantaranya : CV. Kardus Communication Cirebon, Sahila Building Lantai 3, Jalan Klayan Raya 49/64 Cirebon, Jawa Barat; PT Perwanal Saatchi \& Saatchi, Menara Jamsostek (South Tower) lantai 17, Jalan Jenderal Gatot Subroto Kav. 38, Jakarta; PT Indonesia Klikkanan Raya, Jalan Wilis No. 1, Guntur-Setiabudi, Jakarta.

Sedangkan Data Sekunder terdiri dari Kitab Undang-Undang Hukum Perdata, Undang-Undang Nomor 30 Tahun 1999, Peraturan Mahkamah Agung, Surat Edaran 
Mahkamah Agung, Surat Edaran Direktur Jenderal Pajak dan dokumen kontrak, dokumen Rencana Anggaran Biaya, photo-photo dan Artikel dari berbagai media, dan lain-lain

\section{Hasil Penelitian}

Penulis melakukan penelitian terhadap beberapa kasus yang terjadi di berbagai jasa penyelenggara kegiatan dan melakukan pembahasan berdasarkan tinjauan pustaka sebagaimana yang dipaparkan sebelumnya. Diantaranya Kegiatan Perusahaan "Peresmian

\section{PLTP Kamojang Unit 5 \& Groundbreaking Proyek-Proyek Pengembangan} Geothermal" dan Kegiatan Promosi \& Penjualan "JONI CAMPAIGN" obat nyamuk semprot dari Baygon produksi PT Johnson Home Hygiene.

PT PACTO Convex Ltd (Pacto) mendapat kepercayaan dari PT Pertamina Geothermal Energy (PGE) untuk melaksanakan acara Peresmian PLTP Kamojang Unit 5 \& Groundbreaking Proyek-Proyek Pengembangan Geothermal. Pacto menunjuk CV Kardus Communication (Kardus) sebagai mitra kerjanya dalam melaksanakan acara tersebut dikarenakan adanya hubungan baik antara pemilik Pacto dan pemilik Kardus, dan berdasarkan Gentlement Agreement pada tanggal 2 Juli 2015 disepakati bahwa penyelenggaraan acara tersebut akan dilaksanakan oleh Kardus dengan nilai Rp 1.100.000.000,00 (satu milyar seratus juta rupiah). Permasalahan yang timbul pada penyelenggaraan acara tersebut diantaranya : Kesepakatan diterima oleh Kardus dalam waktu 3 (tiga) hari sebelum hari $\mathrm{H}$, hal ini mengakibatkan perubahan pada beberapa jenis pekerjaan dari yang telah disepakati, atas perubahan tersebut Kardus telah mendapat persetujuan dari Pacto secara lisan yakni menjadi sebesar Rp. 1.300.000.000.00 (satu milyar tiga ratus juta rupiah) yang mana setelah acara dilaksanakan Pacto menolak untuk melakukan pembayaran atas jumlah yang ditagihkan dengan berbagai alasan diantaranya adalah kesepakatan awal adalah senilai Rp. 1.100.000.000,00 (satu milyar seratus juta rupiah).

PT Indonesia Klikkanan Raya (Kikan) menjalin kerjasama dengan PT Perwanal Saatchi \& Saatchi (Saatchi) dengan ditandatanganinya Formulir Registrasi Rekanan antara Kikan dengan Saatchi pada tanggal 30 Juli 2015. Saatchi mendapat tawaran dari PT Johnson Home Hygiene untuk melaksanakan acara "JONI CAMPAIGN", kemudian menunjuk dan meminta Kikan untuk membuat penawaran yang kemudian penawaran tersebut setelah 
disesuaikan dengan peraturan Saatchi ditawarkan kepada PT Johnson Home Hygiene dalam Surat Production Estimate (PE) No. SCJ15070001/01 tertanggal 13 Juli 2015 yang kemudian diterima dan disetujui oleh PT Johnson Home Hygiene. Atas diterima penawaran tersebut Saatchi membuat surat Purchase Order (PO) kepada Kikan No. PO 15008162 tertanggal 13 Agustus 2015. Dalam menjalankan event "JONI CAMPAIGN" tersebut terdapat kendala dilapangan dari pihak Kikan diantaranya yaitu : Kurangnya pengetahuan beberapa Sales Promotion Girls (SPG) tentang produk yang ditawarkan mengakibatkan tidak terpenuhinya keingintahuan calon konsumen tentang produk yang ditawarkan, Wilayah promosi di yang luas tidak dibarengi dengan jumlah supervisor yang memadai, hal ini mengakibatkan kurangnya kontrol terhadap beberapa tempat promosi. Berkaitan dengan kendala-kendala tersebut, PT Johnson Home Hygiene (dalam hal ini diwakili oleh Saatchi) memutuskan jangka waktu penyelenggaraan acara yang semula dijadualkan berlangsung selama 1 (satu) bulan diputuskan hanya berlangsung 2 (dua) minggu. Hal ini berimbas pada nilai PO yang semula bernilai Rp. 1.794.680.611,00 (satu milyar tujuh ratus sembilan puluh empat juta enam ratus delapan puluh ribu enam ratus sebelas rupiah) dibatalkan dan turun menjadi Rp.915.833.673,00 (sembilan ratus lima belas juta delapan ratus tiga puluh tiga ribu enam ratus tujuh puluh tiga rupiah).

\section{Pembahasan}

Unsur-unsur dari perlindungan hukum meliputi : adanya wujud perlindungan hukum, subjek hukum, objek perlindungan hukum. Sedangkan prinsip keberlanjutan usaha (going concern principle) adalah asumsi bahwa suatu entitas akan tetap berada dalam bisnis di masa mendatang.

\section{a. Wujud Perlindungan Hukum}

Dalam hukum perikatan sebagaimana yang diatur BUKU III KUHPerdata, yang menjadi tujuan perlindungan kepada subjek hukum yaitu menjamin terpenuhinya hak-hak para pihak dalam perikatan dan mendapat perlindungan berupa penegakan dan kepastian hukum bilamana terjadi sengketa dalam pelaksanaan perikatan tersebut. 


\section{b. Subjek Hukum}

Ilmu hukum mengenal ada dua subjek hukum, yaitu orang dan badan hukum.

1) Natuurlijke Persoon/Natural Person/Manusia Pribadi.

Pasal 1329 KUHPerdata menyatakan bahwa "Setiap orang adalah cakap untuk membuat perikatan-perikatan, jika ia oleh Undang-Undang tidak dinyatakan tidak cakap". Seseorang dikatakan sebagai subjek hukum (pembawa hak), dimulai dari ia dilahirkan dan berakhir saat ia meninggal. Bahkan, jika diperlukan (seperti misalnya dalam hal waris), dapat dihitung sejak ia dalam kandungan, asal ia kemudian dilahirkan dalam keadaan hidup

2) Rechtspersoon/Legal Intitle/Badan Usaha Berbadan Hukum.

Pengaturan dasar dari badan hukum terdapat dalam Pasal 1653-1654 KUHPerdata. Frasa 'badan hukum' mengandung dua dimensi, yakni badan hukum publik (propinsi, kabupaten dan kotapraja) dan badan hukum perdata (Perseroan Terbatas, rederij/perusahaan pelayaran, dan Yayasan). Badan hukum mempunyai kewenangan melakukan perbuatan hukum terbatas pada bidang hukum harta kekayaan.

Badan usaha terbagi dalam badan usaha berbentuk badan hukum (perseroan terbatas, yayasan, koperasi) dan badan usaha bukan berbentuk badan hukum (Persekutuan Perdata, Firma, Persekutuan Komanditer (commanditaire vennootschap atau CV). Manfaat mendirikan badan usaha bagi bisnis adalah sebagai berikut :

a) Sebagai sarana perlindungan hukum (bila memiliki izin usaha berefek memberikan rasa aman dan nyaman akan keberlangsungan usahanya).

b) Sarana promosi (adanya dokumen-dokumen hukum tentang kegiatan usaha, secara tidak langsung pengusaha telah melakukan serangkaian promosi).

c) Bukti kepatuhan terhadap aturan hukum (unsur legalitas menandakan bahwa pengusaha telah mematuhi aturan-aturan hukum yang berlaku). 
d) Mempermudah mendapatkan suatu proses (beberapa jenis usaha tidak terlepas dari proses pemenangan tender suatu proyek, baik dari perusahaan swasta maupun pemerintah, unsur-unsur legalitas yang terkait dengan kepemilikan suatu badan usaha adalah keharusan dalam mengikuti pelelangan sebagai sarana perlindungan hukum).

e) Mempermudah pengembangan usaha (surat izin dan kejelasan legalitas usaha, akan dapat mempermudah mendapatkan tambahan modal dari lembaga keuangan/Bank yang dibutuhkan bagi pengembangan usaha).

\section{c. Objek Perlindungan Hukum}

Syarat sahnya perjanjian menurut pasal 1320 angka (3) KUHPerdata adanya objek tertentu. Obyek adalah sesuatu yang diperjanjikan dalam suatu perjanjian haruslah suatu hal atau barang yang cukup jelas. Artinya objek yang diatur kontrak harus jelas untuk memberikan jaminan atau kepastian kepada pihak-pihak dan mencegah timbulnya kontrak fiktif.

\section{d. Perlindungan Hukum Terhadap Bisnis Jasa Penyelenggara Kegiatan.}

Definisi jasa penyelenggara kegiatan tertera dalam Surat Edaran Direktur Jenderal Pajak Nomor SE-11/PJ.53/2003 tentang Perlakuan Pajak Pertambahan Nilai Atas Jasa Penyelenggara Kegiatan angka (1) huruf (a) tanggal 28 Maret 2003 yang merupakan aturan lanjutan dari UU No 8/1983 tentang PPN Barang dan Jasa dan PPn BM yang telah diubah dengan UU No 18/2000 Pasal 4 a Ayat (3) yang berbunyi : Jasa penyelenggaraan kegiatan (Event Organizer) adalah kegiatan usaha yang dilakukan

oleh Pengusaha Jasa Penyelenggara Kegiatan antara lain kegiatan berupa penyelenggaraan pameran, pameran konvensi, pergelaran musik, pesta, seminar, peluncuran produk, konferensi pers, dan kegiatan lain yang memanfaatkan jasa penyelenggara kegiatan, termasuk di dalamnya yang mendukung kegiatan tersebut baik atas permintaan dari pengguna jasa penyelenggara kegiatan maupun diselenggarakan sendiri oleh Pengusaha Jasa Penyelenggara Kegiatan. 
Penyelenggaraan kegiatan terlahir dari keinginan pihak yang mempunyai dana (pengguna jasa), dimana mereka memiliki tujuan yang diharapkan dapat mencapai tujuannya dengan melakukan rangkaian kegiatan. Pengguna jasa memberi briefing mengenai maksud dan tujuan yang ingin mereka capai, sementara untuk kreatif dan eksekusinya diserahkan kepada perusahaan jasa penyelenggara kegiatan yang ditunjuk. Di sinilah peran perusahaan jasa penyelenggara kegiatan yaitu membantu mewujudkan harapan dan tujuan dari pengguna jasa.

Sampai saat ini ada beberapa perusahaan jasa penyelenggara kegiatan yang belum berbadan hukum tetapi sukses dan mampu bertahan, namun bagi perusahaan jasa penyelenggara kegiatan yang membidik pasar sasaran perusahaan-perusahaan besar haruslah berbadan hukum. Hal ini disebabkan perusahaan besar memiliki standar dalam memilih perusahaan jasa penyelenggara kegiatan sebagai rekan kerja. Perusahaaan jasa penyelenggara kegiatan yang dianggap professional adalah yang sudah berbadan hukum, mereka juga bertanggung jawab atas semua pengeluaran yang dikenakan pajak, oleh karenanya legalitas menjadi penting.

Perusahaan jasa penyelenggara kegiatan tidak hanya menjual barang, ia menjual sesuatu yang tak berwujud (intangible assets) berbeda dengan perusahaan dagang yang menyediakan atau menawarkan suatu yang berwujud. Ciri-ciri perusahaan jasa yang membedakannya dengan perusahaan jenis lain yaitu ; perusahaan jasa tidak menawarkan barang atau produk yang jelas wujudnya, namun dapat dirasakan manfaat atau faedahnya, sulit mengukur standar harga pada jasa yang ditawarkan pada perusahaan jasa (misalnya perusahaan jasa tidak memasok harga tetap melainkan mendapatkan harga melalui tingkat baik tidaknya pelayanan yang mereka lakukan). Ada 3 (tiga) macam intangible assets, yaitu:

1) Human Capital Asset yaitu adalah barisan insani atau Sumber Daya Manusia (SDM) hebat yang ada di dalamnya.

2) Knowledge and Creativity Asset yaitu ilmu yang ingin mengolah semua jenis pengetahuan dan kreativitas SDM dalam sebuah organisasi menjadi kekuatan informasi yang berharga. Knowledge management berusaha meng-ekstrak pengetahuan berharga dalam setiap otak SDM-nya yang unggul (pegawai yang 
dikenal sebagai expert atau manajer senior yang berpengalaman luas); dan membuat pengetahuan berharga itu menjadi mudah di-akses oleh semua pegawainya.

3) Brand Asset yaitu "harga atau nilai" brand yang mereka miliki - jika diuangkan dalam satuan moneter.

Kekuatan intangible asset yang ketiga ini hanya akan muncul jika dua intangible asset yang pertama yakni : human capital dan knowledge asset eksis dalam sebuah perusahaan. Hal inilah yang menciptakan brand legendaris.

Di masa lalu, umumnya negosiasi dan kesepakatan-kesepakaatan dilakukan secara informal, sehingga memberi peluang bagi masing-masing pihak yang terlibat untuk menafsirkan secara bebas kesepakatan tersebut. Dalam sistem bisnis modern dan bernuansa legalitas, hal ini tidaklah cukup, perusahaan jasa penyelenggara kegiatan akan bertanggung jawab secara penuh terhadap kontrak, dan sebagai implikasinya ia akan mengambil semua tanggung jawab hukum atas kontrak tersebut.

Dasar dari dokumen perusahaan jasa penyelenggara kegiatan adalah kontrak. Tanpa sebuah kontrak, acara akan didasarkan pada apa yang diingat orang sebagai aturan. Hal ini mungkin berlaku bagi acara kecil yang tidak formal, tetapi apabila acara yang dilakukan melibatkan para pemasok, publik atau lembaga pemerintah, maka perjanjian tertulis merupakan suatu keharusan. Kontrak bukanlah bagian yang menarik dalam jasa penyelenggara kegiatan namun demikian kontrak dikenal sebagai pusat bagi prosedur yang benar bagi perencanaan dan pelaksanaan suatu proyek. Banyak pihak yang terlibat dalam suatu kegiatan, tidak hanya perusahaan jasa penyelenggara kegiatan, pengguna jasa (sponsor atau pemilik acara), kontraktor (penyedia barang dan jasa), pihak lain yang terlibat diantaranya adalah vendor (pemilik brand, pencipta produk), distributor (penampung produk), supplier (pemasok produk).

Bagaimana vendor dan supplier melakukan upaya untuk mencapai hasil, biasanya bukan hal yang penting bagi perusahaan jasa penyelenggara kegiatan atau pengguna jasa, bagi mereka yang terpenting adalah hasilnya meskipun dalam pelaksanaannya sifat acara yang unik yaitu mudah berubah sehingga dikalangan 
perusahaan jasa penyelenggara kegiatan dikenal istilah "Proyek Roro Jonggrang" yaitu mengerjakan berbagai macam pekerjaan dalam waktu yang relatif sangat singkat. Perusahaan jasa penyelenggara kegiatan dituntut untuk dapat memberikan solusi yang nyata atas setiap situasi yang berkembang dalam suatu acara.

Yang membedakan kontrak pada perusahaan jasa penyelenggara kegiatan dengan yang lain adalah mengesampingkan pentingnya waktu, kontrak merupakan kesepakatan terhadap suatu kejadian yang tidak boleh gagal oleh karenanya kontrak dan administrasinya harus direncanakan hingga ke hal-hal yang sangat rinci. Rencana antisipasi atau cadangan adalah hal penting meskipun tidak harus dimasukkan dalam kontrak tersebut. Kontrak bukanlah suatu dokumen final terhadap berbagai hal, tetapi merupakan sebuah metode untuk memastikan bahwa sasaran pengguna jasa dapat tercapai.

Perusahaan jasa penyelenggara kegiatan menjual asset yang tak berwujud yang tidak meninggalkan wujud yang kasat mata manakala prestasi telah dilaksanakan oleh karenanya kontrak sebagai alat bukti telah dilaksanakannya suatu acara menjadi hal yang wajib.

Dalam perjalanan bisnis jasa penyelenggara kegiatan, perjanjian lisan, LoI, dan MoU seringkali terjadi dan hal ini mengakibatkan perlindungan hukum terutama terhadap perusahaan jasa penyelenggara kegiatan menjadi sulit bilamana terjadi sengketa yang disebabkan tidak adanya hak dan kewajiban para pihak yang diatur secara lengkap, konkret sehingga sulit pula melaksanakan apa yang telah diperjanjikan. Kondisi yang demikian pada akhirnya akan membuat perusahaan jasa penyelenggara kegiatan menjadi tidak sehat dan yang lebih fatal adalah berakhirnya kehidupan perusahaan jasa penyelenggara kegiatan.

\section{e. Pelaksanaaan Bisnis Jasa Penyelenggara Kegiatan}

CV. Kardus Communication Cirebon, PT PACTO Convex Jakarta, PT Indonesia Klikkanan Raya Jakarta, PT Perwanal Saatchi \& Saatchi Jakarta, memenuhi kriteria sebagai Event Organizer dan hubungan hukum perusahaan-perusahaan Event Organizer tersebut dan pengguna jasanya memenuhi kriteria sebagai perikatan, adapun hubungan 
hukum antara perusahaan-perusahaan jasa penyelenggara kegiatan dengan para penggunanya berupa melakukan suatu perbuatan yaitu melaksanakan kegiatan pengguna jasanya seperti "Peresmian PLTP Kamojang Unit 5 \& Groundbreaking Proyek-Proyek Pengembangan Geothermal", Promosi \& Penjualan "JONI CAMPAIGN" obat nyamuk semprot dari Baygon produksi PT Johnson Home Hygiene, Hubungan hukum tersebut ada yang berhasil ada yang tidak berhasil.

Ada kegiatan yang menggunakan kontrak sebagai dasar dilaksanakannya pekerjaan, menggunakan penunjukkan (Purchase Order) dan "gentlement agreement" hal ini merupakan implementasi dari asas kebebasan berkontrak yang memberikan kebebasan kepada para pihak untuk membuat perjanjian dengan bentuk atau format apapun serta dengan isi atau substansi sesuai yang diinginkan para pihak, ketidaktelitian dalam menyusun kontrak mengakibatkan kerugian materil dan immateril. Hal ini juga merupakan implementasi dari asas konsensualisme dalam pasal 1320 KUHPerdata angka (1) mengandung arti kesepakatan dalam perjanjian itu lahir cukup dengan adanya kata sepakat, yang ditekankan adalah adanya persesuaian kehendak (meeting of mind) sebagai inti dari hukum kontrak. Asas Pacta Sunt Servanda melekat pada perjanjian disetiap event yang dilaksanakan, bahkan dibeberapa acara tidak adanya addendum mengakibatkan kehilangan sebagian hak pada salah satu pihak, hal ini berkaitan erat dengan asas itikad baik yang lakukan salah satu pihak tetapi tidak di pihak lain.

Pelaksanaan prestasi akan menghapus eksistensi perikatan, hal ini sebagaimana pasal 1381 KUHPerdata. Perikatan antara perusahaan-perusahan jasa penyelenggara kegiatan dan kliennya dalam melaksanakan kegiatan-kegiatan tersebut ada yang belum hapus dikarenakan masih adanya sisa kewajiban yang belum dilaksanakan (wanprestasi), ada yang sudah hapus dikarenakan adanya pembayaran, sudah hapus karena pembatalan kontrak lama dibuat kontrak baru kemudian dibayar.

Kegiatan-kegiatan yang dipaparkan dikategorikan sebagai kegagalan kontrak, namun perusahaan jasa penyelenggara kegiatan tidak menganggap hal tersebut sebagai kegagalan kontrak. Mereka menganggap sebagai bagian dari risiko bisnis, peneliti berpendapat bahwa Perusahaan jasa penyelenggara kegiatan merupakan pihak yang banyak membutuhkan perlindungan hukum, pemahaman tentang hukum bisnis menjadi suatu kewajiban disebabkan 
pihak perusahaan jasa penyelenggara kegiatan melaksanakan kewajibannya lebih dahulu sedangkan pengguna jasa lebih awal menerima haknya. Adanya permasalahan dalam pelaksanaan kegiatan menyebabkan tertunda bahkan tidak diperolehnnya hak perusahaan jasa penyelenggara kegiatan yang mengakibatkan kerugian baik materil maupun immaterial dan yang terburuk adalah tidak berlanjutnya perusahaan jasa penyelenggara kegiatan. Penyelesaian yang terbaik dan ideal adalah pola-pola win-win solution, terutama melalui Alternatif Dispute Resolution (ADR), antara lain meliputi konsultasi, negosiasi, mediasi, konsiliasi maupun penilaian ahli. Melalui wadah ini keberadaan para pihak terlindungi, kredibilitas maupun bonafiditas para pihak tetap terjaga.

\section{Simpulan dan Rekomendasi}

1. Suatu perjanjian jasa penyelenggara kegiatan harus dibuat secara sah sebagaimana Pasal 1338 ayat (1) KUHPerdata yang berpedoman pada syarat-syarat perjanjian pada Pasal 1320 KUHPerdata, kedua pasal tersebut memiliki azas kebebasan berkontrak, konsensualisme, Pacta Sunt Servada, dan itikad baik. Apabila kedua pasal tersebut terpenuhi maka salah satu pihak berhak menerima pembayaran dan pihak lain berkewajiban memenuhi pembayaran sebagaimana pasal 1382 KUHPerdata. Kendalakendala dalam pemenuhan hak dan kewajiban disebabkan adanya ketidaktahuan, ketidakmampuan ataupun ketidakmauan para pihak termasuk pihak luar yang berkaitan erat dengan jasa penyelenggara kegiatan dalam melaksanakan azas-azas perjanjian. Perjanjian merupakan pusat prosedur yang benar bagi perencanaan dan pelaksanaan jasa penyelenggara kegiatan dalam sistem bisnis modern dan bernuansa legalitas.

2. Untuk memenuhi syarat-syarat perlindungan hukum dalam jasa penyelenggara kegiatan maka wujud perlindungan tersebut harus jelas yaitu penegakan dan kepastian hukum dalam pelaksanaan perikatan jasa penyelenggara kegiatan, subjek hukum harus badan usaha berbadan hukum (PT) dalam hal badan usaha adalah CV maka dalam mengajukan gugatan hukum diwakili oleh pengurus CV tersebut, dan objek dari jasa penyelenggara kegiatan harus sesuai dengan Pasal 1320 angka (3) KUHPerdata adanya objek tertentu. Bilamana terjadi sengketa maka mediasi baik di Pengadilan 
sebagaimana PERMA No.1 Tahun 2016 maupun di luar Pengadilan sebagaimana UU No. 30 tahun 1999 adalah solusi terbaik.

3. Perusahaan jasa penyelenggara kegiatan merupakan pihak yang banyak membutuhkan perlindungan hukum, hal ini disebabkan pihak perusahaan jasa penyelenggara kegiatan melaksanakan kewajibannya lebih dahulu sedangkan pengguna jasa lebih awal menerima haknya, adanya permasalahan dalam penyelenggaraan kegiatan menyebabkan tertunda bahkan tidak diperolehnnya hak perusahaan jasa penyelenggara kegiatan.

\section{DAFTAR PUSTAKA}

\section{Buku}

Badrulzaman Mariam Darus, 2015, Hukum Perikatan dalam KUH Perdata Buku Ketiga, PT Citra Aditya Bakti, Bandung.

Fuady Munir, 2014, Teori-Teori Besar (Grand Theory) Dalam Ilmu Hukum, PT Kencana Prenadamedia Group, Jakarta

Harahap M.Yahya, 2016, Hukum Acara Perdata, Sinar Grafika, Jakarta.

Hernoko Agus Yudha, 2014, Hukum Perjanjian, Asas Proporsionalitas dalm Kontrak Komersial, PT Kencana Prenadamedia, Jakarta.

HS. Salim, Abdullah, Wahyuningsih Wiwiek, 2014, Perancangan Kontrak \& Memorandum of Understanding (MoU), Sinar Grafika, Jakarta.

HS Salim, Nurbani, 2016, Penerapan Teori Hukum pada Penelitian Tesis dan Disertasi, PT RajaGrafindo Persada, Jakarta

Kusumadara Afifah, 2013, Kontrak Bisnis Internasional-Elemen Elemen Penting dalam Menyusunnya, Sinar Grafika, Jakarta.

Megananda Yudhi, Wijaya Johanes Arifin, 2009, 7 Langkah Jitu Membangun Bisnis Event Organizer, PT Bhuana Ilmu Populer, Jakarta.

Mertokusumo Sudikno, 2006 Hukum Acara Perdata Indonesia, Liberty, Yogyakarta.

O’Toole William, Mikolaitis Phyllis, 2007, Coorporate Event Management, PPM, Jakarta.

Satrio J., 1999, Hukum Perikatan (Perikatan Pada Umumnya), PT Alumni, Bandung.

Soenandar Taryana, 2006, Prinsip-Prinsip UNIDROIT, Sebagai Sumber Hukum Kontrak dan Penyelesaian Sengketa Internasional, Sinar Grafika, Jakarta.

Subekti, 2003, Pokok-Pokok Hukum Perdata, PT Intermasa, Jakarta.

Subekti, Tjitrosudibio R., 2008, Kitab Undang-Undang Hukum Perdata, PT Pradnya Paramita, Jakarta.

Werry P.L., 1990, Perkembangan Hukum tentang Itikad Baik di Netherland, Percetakan Negara RI, Jakarta.

Widjaja Gunawan, Muljadi Kartini, 2003, Seri Hukum Perikatan : Perikatan Yang Lahir Dari Undang-Undang, PT RajaGrafindo Persada, Jakarta. 


\section{Artikel Jurnal}

Purwanto Harry, November 2011, Keberadaan Asas Rebus Sic Stantibus Dalam Perjanjian Internasional, , Mimbar Hukum, Jurnal berkala Fakultas Hukum Universitas Gadjah Mada.

\section{Makalah/Pidato}

Guest A.G., Zwieght Konrad dan Kotz Hein, 2003, Khairandy, Itikad Baik dalam Kebebasan Berkontrak, FH UI : Pascasarjana, Jakarta.

Pramono Nindyo, 6-7 September 2006, Kontrak Komersial: Pembuatan dan Penyelesaian Sengketa", dalam acara Pelatihan Hukum Perikatan bagi Dosen dan Praktisi, Fakultas Hukum Universitas Airlangga, Surabaya.

\section{Peraturan Perundang-undangan}

Kitab Undang-Undang Hukum Perdata

Herzien Inlandsch Reglement

Rechtsreglement Voor De Buitengewesten

Undang-Undang Nomor 30 Tahun 1999

Peraturan Mahkamah Agung

Surat Edaran Mahkamah Agung

Surat Edaran Direktur Jenderal Pajak

Kitab Undang-Undang Hukum Pidana 